\title{
POSISI BAHASA ARAB DI DUNIA ISLAM
}

\author{
Aida Aqsanti Nasution \\ Sekolah Tinggi Agama Islam Negeri (STAIN) Sorong, Papua Barat, Indonesia \\ Email : aidaaqsantinasution@gmail.com
}

\begin{abstract}
ABSTRAK
Bahasa arab adalah bahasa agama yang merupakan Al-Quran dan menjadi salah satu alat komunikasi internasional yang dipelajari untuk membagi pengetahuan seseorang kepada orang lain dan memelihara keberadaan tradisi serta kebudayaan, yang dipelajari tidak hanya penduduk di wilayah Arab Saudi saja tapi juga di wilayah Negara lainnya. Bahasa arab juga suatu sistem pembelajaran yang ideal mampu mengantarkan manusia menguasai keterampilan-keterampilan bahasa. Oleh karena itu, mempelajari bahasa arab menjadi kebutuhan setiap orang khususnya umat islam.
\end{abstract}

\section{PENDAHULUAN}

Manusia pada hakikat nya hidup dengan menggunakan berbagai bahasa, salah satunya umat islam menggunakan bahasa arab sebagai alat media komunikasi, mengepresikan pikiran, gagasan, ataupun perasaan. Penggunaan bahasa arab sebagai bahasa asing makin mapan dengan keputusan pemerintah Indonesia memilih bahasa arab sebagai bahasa asing.

Bahasa arab merupakan bahasa asing yang dianggap penting sebagai sarana untuk penyerapan dan pengembangan ilmu pengetahuan, teknologi, seni budaya, dan pembinaan hubungan dengan bangsa-bangsa lain. Hal ini membuktikan bahwa bahasa arab merupakan bahasa yang penting untuk dipelajari dalam hubungannya dengan pendidikan dan peningkatan kualitas individu.

\section{PERANAN BAHASA ARAB DALAM KEBUDAYAAN NASIONAL}

Bahasa arab merupakan bahasa yang sering di gunakan sebagai wujud bahasa sehari-hari. Maka dari itu penggunaan bahasa arab sebagai bahasa Al-quran pun sesungguhnya lebih banyak menyangkut masalah teknisi penyampaian pesan dari pada 
masalah nilai. Bahasa arab dalam masyarakat dan kebudayaan Indonesia telah mengambil bagian yang sangat penting sejak perkembangan islam di nusantara pada abad ke tiga belas masehi. Hingga kini pengaruh bahasa arab masih bisa di rasakan dan dapat di lihat dengan nyata bahwa bahasa arab tidak hanya merupakan bahasa agama islam yang hidup dilingkungan ulama, pesantren, madrasah, cendikiawan dan masyarakat islam.

Di sebagian masyarakat ada yang meyakini meskipun terkadang bersentuhan dengan keyakinan yang keliru bahwa ayat-ayat suci Al-quran dan hadis yang bertuliskan kata-kata arab. Selain itu, ada beberapa ungkapan berbahasa arap yang di ambil dari ajaran yang sering di gunakan, baik dalam forum resmi maupun tidak resmi seperti ucapan salam "assalamu'alaikum warahamatullahi wa barakatuh", "bissmillahirrahmanirrahim", "Alhamdulillah", “masya allah”, dan "insya allah". Ungkapan-ungkapan yang disebutkan tersebut telah di gunakan secara meluas, baik oleh rakyat biasa maupun pejabat tinggi pemerintahan.

Hingga kini pun huruf arab merupakan huruf yang harus dipelajari secara mendalam, khususnya bagi mereka yang memperlajari kesastraan Indonesia. Karena itu, munculah "huruf -huruf arab baru" misalnya huruf arab melayu di Malaysia, "huruf-huruf arab baru" lazim di sebut "huruf jawi". Dengan media tulisan berhuruf arab melayu, ratusan judul buku yang membahas persoalan-persoalan ibadah, hikayat, tasawuf, sejarah nabi dan rasul.

\section{BAHASA ARAB DAN KEINTERNASIONALAN}

Bahasa arab merupakan salah satu bahasa yang digunakan pada ayat suci Al-quran dan pertama kali di lafalkan oleh nabi Adam Alaihisalam. Dan juga bahasa yang tidak bisa dipisahkan oleh umat muslim. Bahasa-bahasa yang pernah menjadi bahasa Internasional dalam sejarah adalah bahasa Akadiyyah, Aramiyyah (Aramic), Yunani, Latin, dan Bahasa Arab. Sampai pada masa sekarang ini, bahasa arab merupakan bahasa yang tetap bertahan akan keinternasionalannya, sejajar dengan kedua bahasa internasional modern yakni bahasa inggris dan perancis. Angka 0,1,2,3,4,5, dan seterusnya merupakan kontribusi Arab yang besar sekali sumbangannya terhadap usaha mempermudah hitungan dan penulisan angka tersebut dinamai "Arabic Numerals". Pada abad ke-7 Masehi, bertepatan dengan lahirnya agama islam, kehebatan seseorang berbahasa arab yang dapat di jadikan 
kebanggaan diukur oleh kemampuannya menjelaskan dan mengkomunikasikan alur pemikirannya dengan baik (husn al-bayan) dengan memakai bahasa yang mengandung sastra yang tinggi.

Belum cukup satu setengah abad islam mekar, kedaulatan islam telah mencakup Iraq, Syria, mesir, dan afrika utara. Penduduk wilayah tersebut berbondong-bondong masuk islam (la 'an karhin). Dr. Ibrahim Anis (1970:277) menjelaskan bahwa kesiapan sebagai penduduk wilayah tersebut menerima dan memakai bahasa arab jauh lebih cepat dibanding penerimaan mereka terhadap agama islam itu sendiri. Dengan demikian, dalam kurun waktu abad, bahasa arab telah menjadi bahasa internasional sampai ke Persia (Iran), seluruh Iraq, sebagian Asia kecil tepat nya di suku Doria tempat ini kini menjadi bagian dari Negara turki, Negara-negara di Afrika Utara dan Andalus untuk beberapa abad.

\section{BAHASA ARAB DI TENGAH-TENGAH BAHASA DAN BANGSA LAIN}

Setelah beberapa wilayah ditaklukan oleh kaum muslimin, bahasa arab menjadi bahasa utama didaerah baru tersebut. Di Syria dan Iraq, bahasa internasional waktu itu adalah yunani. Bahasa arab juga pernah berbenturan dengan bahasa internasional lain antara lain : bahasa aramiyyah yang pernah di artikulasikan orang Iraq dan Syria, serta beberapa wilayah di mesir. Bahasa tersebut pernah seiring dengan bahasa yunani sampai berabad-abad. Hanya saja bahasa Aramiyyah sekandung dengan bahasa arab.

Terhadapat bahasa latin, bahasa arab tidak pernah berbenturan. Walaupun begitu bahasa latin mengalami kemerosotan dengan sendirinya ketika bahasa arab berkembang dengan pesat nya. Pada waktu bahasa arab masuk ke wiliyah mesir, kebanyakan orang mesir berbahasa Qibti. Bahasa ini merupakan fasilah lain dari bahasa arab. Terakhir bahasa Qibti pun mengalami kemunduran dan hanya terpakai di gereja-geraja sebagai bahasa kedua setelah bahasa arab.

Sejak akhir abad ke-19, banyak orang arab yang imigran ke Negara-negara lain, seperti ke Negara-negara eropa dan amerika serikat, mereka tinggal, belajar, berdagang. Di Amerika banyak jutaan orang arab telah berbicara bahasa inggris, tetapi mereka juga menyadari akan bahasa nenek moyang mereka. Disini, mereka berusaha menjadikan bahasa arab hidup di sekolah-sekolah dan rumah-rumah mereka. Di antara orang Arab dan 
Amerika yang terkemuka misalnya Ralph Nader, seorang consumer advokat; Dhany Thomas, seorang entertainer, kepala protokol Gedung Putih; khalil Gibran, seorang penulis terkenal dengan karyanya diterjemahkan ke dalam beberapa bahasa. sang penulis meninggal pada tahun 1931.

\section{KESIMPULAN}

1. Bahasa Arab adalah bahasa yang paling istimewa, di dalam nya paling banyak pengungkapan yang dapat menenangkan jiwa dan mempunyai peranan yang sangat besar di berbagai dunia, karena dalam setiap bahasa pasti memiliki manfaat yang dapat di ambil, seperti hal nya bahasa arab, di samping pengetahuan tentang keagamaan khususnya agama islam dapat kita pelajari, karena kunci dari al-quran yang merupakan kitab suci umat islam adalah ditulis dalam bahasa arab.

2. Bahasa arab merupakan bahasa manusia, baik muslim maupun non muslim. Bahasa arab merupakan bahasa internasional yang salah satu ciri keinternasionalnya telah berperan meningkatkan dinamika kehidupan. Bahasa arab perlu di pahami dan di pelajari untuk semua orang.

3. Keluasan penyebaran wiliyah Arab mencakup beberapa bangsa yang berbeda-beda. Bahasa arab telah membuat bahasa Barbar mundur sampai ke gurun-gurun pasir. Terhadap bahasa Persia, bahasa arab mengalami penyelarasan dan interaksi positif karena islam terbantu oleh bahasa dan kebudayaan Persia, sehingga di beberapa daerah muslim, bahasa Persia menjadi bahasa kedua setelah bahasa arab.

\section{DAFTAR PUSTAKA}

Sukamto, I. dan Akhmad M. (2000). Tata Bahasa Arab Sistematis. Yogyakarta : Nurma Media Idea

Arsyad dan Azhar. (2003). Bahasa Arab dan Metode Pembelarannya. Yogyakarta : Pustaka Belajar

Izzan, A. (2007). Metodologi Pembelajaran Bahasa Arab. Bandung : Humaniora 